\title{
THE SERVICEMAN AND VICARIOUS LIABILITY
}

On December 15, 1950 the President of the United States declared anotbed national emergency and directed that the armed forces be enlarged to three and a half million men by tbe Spring of 1951. With this tremendous increase in mobilization the problem of claims against the Government for torts of setvicemen will become increasingly acute.

The initial axiom to be kept in mind is that the sovereign is immune from suit. ${ }^{1}$ Accordingly, any right to sue the National Government must spring from a legislative grant; and all doubts will be resolved in favor of the sovereign. ${ }^{2}$ The Federal Tort Claim Act contains such a grant; it recognizes that just as an employee's torts can judicially be viewed as part of an ordinary employer's cost of doing business, $^{8}$ so can the torts of Government employees be viewed as a part of the cost of Government.

The pertinent portions of the Federal Tort Claims Act of 1945 are:

a. 28 U.S.C. $\$ 1346$ (b) "District Courts . . . shall have exclusive jurisdiction of civil actions on claims against the United States, for money damages accruing on or after 1 January 1945, for injury or loss of property, or personal injury or death caused by the negligent or wrongful act or omission of any employee of the Government while acting within the scope of his office or employment, under circumstances where the U.S., if a private person, would be liable to the claimant in accordance with the law of the place where the act or omission occurred."

b. 28 U.S.C. \$2671 "Acting within the scope of his office or employment in the case of a member of the military or naval forces of the United States, means acting in line of duty."

c. 28 U.S.C. $\$ 2764$ "The United States shall be liable, respecting the provisions of this title to tort claims, in the same manner and to the same extent as a private individual under like circumstances, but shall not be liable for interest prior to judgment or for punitive damages."

2 Osborn v. Bank of U.S., 9 Wheat. 738, 22 U.S. 738 (1824); U.S. v. Shaw, 309 U.S. 495 (1939).

2 Hammond-Knowlton v. U.S., 121 F.2d 192 (1941); For excellent discussion on subject prior to Federal Tort Claims Act, see "Governmental Responsibility," 34 Yale L.J. 1, (1924), 36 Yale L.J. 1, (1926).

s Prosser, Torts, 472, (1941). 
Corporal John Doe, while driving a vehicle of the United States Government, negligently runs into and causes injury to a private citizen, Mr. Smith. Within the provisions of the above quoted sections of the Federal Tort Claims Act lies Smith's authority to sue the United States Government for Corporal Doe's tort.

\section{I. "Scope of Employment" or "Line of Duty"}

The Tort Claim Act, in the case of a member of the military services, defines "acting within the scope of his office or employment". to mean "acting in the line of duty." The formula "within the scope of his employment," vague though it be, grew up to express vicarious liability in situations where there was a degree of departure by the employee from the kind of work he is employed to perform. Authorized limits of time and space and a purpose to serve the master are factors bearing on whether this formula applies to impose vicarious liability in a particular case..$^{5}$

"In line of duty" has achieved whatever definiteness it has in military understanding in the course of administrative adjudication of certain rights and benefits to which servicemen become entitled as a result of injuries and diseases incurred in line of duty. ${ }^{\circ}$ In some respects this military concept has been extremely broad. So it has been held that death of a soldier in a motorcycle accident on a trip to obtain personal laundry was in line of duty, that the death of a soldier from drowning on a trip to obtain equipment

- 28 U.S.C. $\$ 2671$.

- Restatement, Agency, 8 228; seèe also Prosiser, Torts, 475.

- Supplementary Materials on' Elementary LaW, Dept. of Law, U.S. M.A., West Point, N.Y. (1945). "If there is an administrative finding that disabillty or death was not incurred "in line-of dnty," the following may be withheld: A. Disability benefits and pensions; B. Temporary insurance benefits; C. Burial Expenses; $D$. Medical and hospital treatment and domiciliary care; E. Retirement benefits; F. Posthumous appointments and promotions." "An administrative finding that disability or death was incurred as a result of misconduct usually results in the following: A. Making good time lost; B. Forfelting of pay for time lost; C. Loss of six months' gratuity pay; D. Loss of medical care after discharge; E. No admittance to Soldiers' Home; F. Unfavorable type of discharge."

Dig. Op. JAG 1912-40, 960. 
was in line of duty, ${ }^{8}$ and that a soldier on farm furlough who died of disease contracted without fault of his own was in line of duty at the time of his death.9 Further, decisions have been rendered to the effect that a soldier on pass injured while working in a cannery, an occupation encouraged by the War Department to relieve labor shortage, was in line of duty, ${ }^{10}$ that disability of a soldier on furlough while assisting in extinguishing a fire was in line of duty since failure to render assistance under such circumstances would be a reflection on the military service; ${ }^{11}$ and that death of an officer on duty status while engaged in normal and proper recreation was in line of duty. ${ }^{12}$ Obviously this concept is a departure from the traditional agency concept of "within the scope of employment."

On the other hand, there are limitations on the status, "in line of duty," which may make the term narrower than "scope of employment." "A finding of misconduct requires a finding of not 'in line of duty.' "13 Accidental death occurring to a soldier during an absence without leave, ${ }^{14}$ disability or death of a prisoner shot while attempting to escape, ${ }^{15}$ and death of a soldier employed on a railroad resulting from violating railroad rules ${ }^{16}$ were held not to be incurred in line of duty since resulting from misconduct. Since negligence and intentional infliction of harm may properly be considered "misconduct," one might conclude that this would take the serviceman outside the line of duty in most instances where he injures another. However, apparently simple negligence is not viewed by the military as misconduct, for the death of a soldier from negligent driving of a government vehicle was held not to be the result of misconduct.17 Similarly, the injury of an officer in an auto accident when he failed to stop at a stop sign was held under

\footnotetext{
Dig. Op. JAG 1912-40, 956.

- Dig. Op. JAG 1912-40, 971.

10 Bull. JAG, Nov. 1943, 478; Sec. IV, Cir. 321, WD, 11 Dec. 1943.

I2 Dig. Op. JAG 1912-40, 970.

I2 Dig. Op. JAG 1912-40, 966.

13 Same as note 6, "Line of Duty Status," Sec. I(3), 1945.

14 Dig. Op. JAG 1912-40, 972.

20 Dig. Op. JAG 1912-40, 973.

16 Dig. Op. JAG 191240, 970.

${ }^{37}$ Dig. Op. JAG 1912-40, 972.
} 
all the circumstances to be in line of duty and not the result of misconduct, ${ }^{18}$ and the disability or death of a soldier while trespassing on railroad property has been held to be in line of duty and not misconduct, since trespass is not such a violation of duty as constitutes misconduct. ${ }^{19}$ Yet certain types of gross negligence have been held to be sufficient to take the serviceman outside the "line of duty," due to misconduct. For instance, the disability or death of a soldier in an auto accident caused by recklessly driving in violation of speed laws was held not in line of duty as resulting from misconduct..$^{20}$ The death of a soldier due either to intoxication or careless driving is not in line of duty since it is the result of "misconduct."21

It is conceivable that the Congress intended by $\$ 2671$ to adopt the military concept of "in line of duty," as established by the Judge Advocate General, as the test to determine vicarious liability of the Government when servicemen are involved. Of course, if Congress so intended, vicarious liability would have been very wide in many instances, but very narrow in others because of the military view that certain types of misconduct take the serviceman's action outside the "line of duty." Though the Federal Tort Claims Act states in one section that "acting within the scope of his office or employment" shall mean "acting in line of duty,"22 another section states that the United States shall be liable "under circumstances where the U.S., if a private person, would be liable to the claimant." 23 The resulting inconsistency between "line of duty" and the "scope of employment" test which would determine the liability of a private person has been resolved by the Federal Courts in favor of the more familiar "scope of employment" test.

As a result of the adoption of the "scope of employment" test the Federal Courts have held the United States not to be liable for an accident resulting from the negligent driving of a soldier who had gone some 45 miles out of his

18 Bull. JAG, February 1944, 89.

29 Bull. JAG, March 1944, 130; Bull. JAG, April 1944, 177.

so Dig. Op. JAG 1912-40, 961, 962.

a Dig. Op. JAG 1912-40, 954.

$=28$ U.S.C. \& 2671 .

228 U.S.C. \& 1346 (b). . 
assigned route but was on his way back to his assigned station at the time of the accident; ${ }^{24}$ not liable for injuries sustained when a sailor, who was travelling under government orders, negligently ran into the plaintiff when running to catch a train which was moving out of the station; ${ }^{25}$ not liable for negligent driving of an officer who was on his way to a newly assigned station and had been granted a 15 day delay en route, though his orders directed that he drive his own personal car; $;^{26}$ and not liable for negligent driving of a naval officer who was on weekend pass. ${ }^{27}$ Some of the above cases are reminiscent of the employer's non-liability for torts of employees while going and coming from work, but are hardly consistent with the traditional military concept of "in line of duty." In the cases above cited, it is clear that the Judge Advocate General would have held that the serviceman was "in line of duty" had he been injured at the time of the accident, and yet the Federal Courts have denied liability of the United States on the grounds that the said serviceman was not within the "scope of his employment."

It is reasonably arguable that the relationship which exists between a serviceman and the service should result in broadening the application of the "scope of employment" test. If "control" of an employer over an employee is to be any criterion, vicarious liability for torts of a serviceman should perhaps be more readily imposed than in the case of other employees. As an example, consider the case of Bock v. U.S., wherein the Federal Courts denied liability of the United States for the negligent driving of an officer while proceeding from his old station in North Carolina to his newly assigned station in Texas. The officer was directed to drive his own car, for which he would receive compensation upon arrival. At the time of the accident, he was following the most direct route to his new station. During the entire trip the officer was subject to the "control" of the military forces (Military Police have authority to ar-

21 Cropper v. U.S., 81 F.Supp. 81 (N.D. Fla. 1948).

23 U.S. v. Campbell, 172 F.2d 500 (Fifth Cir. 1949).

28 U.S. v. Eleazer, 177 F.2d 914 (Fourth Cir. 1949).

27 Bock v. U.S., 92 F.Supp. 715 (S.D., N.Y. 1950). 
rest and confine members of the military at any time for misconduct, even to include being out of uniform); and further he would have been subjected to penal action by a Military Court Martial had he refused to go to his new station or had he failed to arrive at the assigned time. Such control over employees is completely beyond the comprehension of civilian employers. It is true that civilian employers may direct that an employee perform duties at assigned places and times and the employee may be subject to discharge unless he complies. In the case of a serviceman, however, compliance is insured by virtue of the threat of punishment for non-compliance.

Due to this "control" which the service has over servicemen, it is seriously questioned whether there is complete analogy to civilian employment, where a member of the armed forces is involved. Therefore, it might be asked whether the words, "under circumstances where the U.S., if a private person, would be liable . .." really prescribe complete conformity to civilian "scope of employment."

\section{Application of Federal or State Law.}

Having rejected the federal concept of "line of duty" as a measure of the vicarious liability of the Government for the torts of servicemen, the Courts face the issue whether "scope of employment" is to be determined under Feder"al or State law. The Federal Tort Claims Act precludes the result of decisions under the Federal Employer's Liability Act in determining whether State or Federal substantive law is to apply. In Urie $v$. Thompson, ${ }^{28}$ the United States Supreme Court said, "What constitutes negligence for the statute's [The Federal Employer's Liability Act] purposes is a federal question, not varying in accordance with the differing conceptions of negligence applicable under State and local law for other purposes. Federal decisional law formulating and applying the concept governs."

On the other hand, Section 1346(b) of the Tort Claims Act states that the United States shall be liable "under circumstances where the U.S., if a private person, would

Urie v. Thompson, 337 U.S. 163 (1948). 
be liable to the claimant in accordance with the law of the place where the act or omission occurred."29 Whether this clioice of policy is better than that of the Federal Employer's Liability Act may justly be debated. Be; that as it may, this provision of the Statute has resulted in consistent holdings to the effect that the State law applies. ${ }^{30}$ In applying the State test of "within the scope of his employment," the doctrine of "frolic and detour" lias presented itself on several occasions. There being a division of authority as to the doctrine and its consequences, 31 the Federal Courts have applied the law of the State in which the accident occurred to determine the applicable rule, as this is nothing more than a sub-division of the test of "within the scope of employment."32

$\infty$ Does the provision of this section change the rule of Conflicts of Laws? "The place of the wrong the law of which governs torts is the place where an injury is suffered rather than the place where the act which caused the injury was committed." 15 O.J.S. $\$ 12$ (a) (2), 8991 . It is suggested that it does not for the rule as to torts is usually stated as, "the law of the place where the act or omission claimed as the basis of the tort occurred governs ..." 15 C.J.S. 812,898 , which is very similar to the wording of the act. Obviously the first rule above quoted has reference to the unusual situation where the act occurs in one state and carries over to another state where the injury is inflicted as a result thereof. Should this problem present itself under the Federal Tort Claims Act, it is believed that the Federal Courts will also apply the law of the place where the injury occurred.

song v. U.S., 78 F.Supp. 35 (S.D. Calif. 1948). See also: Cropper v. U.S., supra.; Murphey v. U.S., 179 F.2d 743 (9th Cir. 1950); U.S. v. Eleazer, supra.; Bock v. U.S., supra.

"Prosser, Torts, 477. "As to detour cases various tests have been proposed:

a. Makes the question turn primarily on the servant's motive in the deviation (motivation-deviation test), saying that he is within his employment while he intends in part to serve his master, or as soon as he starts to return to his route.

b. The second test looks to the foreseeabllity of such a deviation and holds the employer liable only for torts occurring in a "zone of risk" within that which the servant might be expected to deviate. Here the employer does not come into the employment until he is reasonably near the authorized route."

\& Lowe v. U.S., 83 F.Supp. 128 (1949); Cropper v. U.S., supra.; Long v. U.S., 78 F.Supp. 35 (1948); Murphey จ. U.S., supra.; U.S. v. Johnson, 181 F.2d 577 (1950). 


\section{Applicability of. Local State Rules of Presumptions}

Suppose that the accident occurs in a jurisdiction where a statute is in effect which makes an auto-owner liable for negligence of a person driving with the owner's permission without regard to whether such person was in the owner's service. Or, again suppose that by statute, mere ownership gives rise to an inference that the driver was acting with the permission of the owner. Section 2674 states that "The United States shall be liable ... in the same manner and to the same extent as a private individual under like circumstances ...." If one looks solely to these words, it would appear that the intent of the Legislature was to make statutes, of the type mentioned, as applicable to the United States as to others. But $\$ 1346(\mathrm{~b})$ provides that the United States shall be liable for wrongful acts or omissions of employees of the Government, "while acting within the scope of his office or employment, under circumstances ..." Interpreting this section, the Federal Courts have held that a plaintiff may not avail himself of local statutory rules that would aid in proving that the serviceman was "within the scope of his employment" at the time of the accident. ${ }^{34}$ In other words, the Federal Courts have said that even though the State test of "within the scope of his employment" is to apply, the burden of proving such a status is not to be relaxed by local statutes or rules of procedure. One explanation for such an interpretation may well be the hesitancy of our Courts to remove the cloak of Governmental immunities.

\section{Conclusions.}

Justice Cardozo once said, "The exemption of the sovereign from suit involves hardship enough where consent

s 28 U.S.C. $\$ 1346$ (b).

s6 Murphey v. U.S., supra., State statute in effect creating a cause of action against an auto owner for negligence of a person driving with the owner's permission, without regard to whether such person was in the owner's service, the court holding that the statute was not applicable to a suit in which the U.S. was involved as defendant. See also Long v. U.S., 78 F.Supp. 35 (1948), and Hubsch v. U.S., 92 F.Supp. 874 (1950). 
has been withheld. We are not to add to its rigor by refinement of construction, where consent has been announced."s5 As to liability for torts of servicemen, have not the Federal Courts imposed an overly refined construction on the provisions of the Tort Claims Act? Have they not forgotten, "It is a wholesome sight to see the Crown sued and answering for its torts"?

E. N. ROBINSON.

* Cited in Rushford v. U.S., 92 F.Supp. 871 (1950).

* Maitland, Collected Papers, 214, 236, (1911). 